\title{
Assessment of Medical Students' Perception of Educational Environment
}

\author{
Asmita Phadke', Jayshree Kharche', Savita Vaidya ${ }^{2}$ \\ ${ }^{1}$ Associate Professor, Department of Physiology, Bharati Vidyapeeth (Deemed to be University) Medical College, \\ Pune, ${ }^{2}$ Former Professor \& Head, Department of Physiology, Bharati Vidyapeeth (Deemed to be University) \\ Medical College, Pune
}

\begin{abstract}
Background: Educationists have established the importance of educational environment in learning. Educational environment is one of the most important factors determining the success of effectiveness of a curriculum. As there was no data available regarding educational environment at our institute; we undertook this study using Dundee Ready Educational Environment Measure (DREEM) to assess students' perception of educational environment at our institute.
\end{abstract}

Method: 60 students of $6^{\text {th }}$ semester were included in the study. Students were administered Dundee Ready Educational Environment Measure (DREEM).

Results: We found the mean global DREEM score of our study population to be $121.47 \pm 13.71$ (out of 200). Problem areas identified were - teaching being too teacher centered \& factual, teacher being authoritarian, students feeling lonely, bored \& stressed out due to academic burden, issue of cheating, no support system for students.

ConclusionThe present study revealed that students perceived the learning environment at our institute positively. Nevertheless, the study also revealed problematic areas of learning for which we need to put some remedial strategies in place.

Key words: educational environment, Dundee Ready Educational Environment Measure (DREEM).

\section{Introduction}

Medical students experience a variety of learning activities in the environs of the medical college. Educational environment is one of the most important factors determining the success of effectiveness of a curriculum $^{1}$. The world over, medical educators are attempting to reform the educational environment so as to make it student friendly without compromising the standards and the quality of learning. Many instruments are available to measure educational environments in undergraduate professional healthcare education, each of which has its own strengths and weaknesses in terms of design, validity and reliability. One of such instruments is the Dundee Ready Educational Environment Measure $(\text { DREEM })^{2}$. DREEM is a 50 item inventory, consisting of 5 subscales. It was originally developed at Dundee and has been validated as a universal diagnostic inventory for assessing the quality of educational environment of different institutions ${ }^{3,4,5,6,7}$. So, in our study, we decided to use Dundee Ready Educational Environment Measure (DREEM) to assess students' perception of educational environment $\&$ aimed at identifying weak areas in educational environment $\&$ to institute remedial measures to rectify them.

\section{Material \& Method}

This was a cross-sectional, questionnaire-based study; data was collected in the year 2015. The medical curriculum in our college is traditional and discipline-based. The course consists of nine semesters over four and a half years followed by one year of internship. Preclinical subjects (anatomy, physiology $\&$ biochemistry) are taught in the first two semesters. Paraclinical subjects (pharmacology, pathology, microbiology, forensic medicine \& toxicology) are 
taught in next three semesters. During this period they also have a limited exposure to medicine, surgery, obstetrics \& gynaecology, paediatrics and community medicine. Students are exposed to all clinical subjects in next four semesters.

\section{Study instrument}

We used Dundee Ready Educational Environment Measure (DREEM). The questionnaire had 50 items \& assessed five domains:

a.Students' perceptions of learning - 12 items,

b.Students' perceptions of teachers - 11 items,

c.Students' academic self-perception - 8 items,

d.Students' perceptions of atmosphere -12 items and

e.Students' social self-perception - 7 items.

Each item was to be rated on a 5-point Likert scale from 0 - 4 where

$0=$ strongly disagree, $1=$ disagree, $2=$ unsure, $3=$ agree, and $4=$ strongly agree. There were nine negative items (items 4, 8, 9, 17, 25, 35, 39, 48, and 50), for which correction was made by reversing the scores; thus after correction, higher scores indicated disagreement with that item. The maximal global score for the questionnaire was 200 and the global score was interpreted as follows:

$0-50=$ Academic environment is very poor;

51-100 = Academic environment has many problems;

101-150 = Academic environment is more positive than negative;
151-200 = Academic environment is excellent.

\section{Study population}

Our subjects were 60 students of $6^{\text {th }}$ semester studying at our institute. Students unwilling to take part in the study were excluded. After obtaining approval from institutional ethical committee, students were briefed about the purpose \& process of the study. Meanings of some of the terms such as 'course organizers' and 'registrars' were explained. It was also explained that the data would be used for quality assurance as well as for research purpose and their co-operation was requested. The students were instructed not to disclose their identity (by roll number or name) to ensure truthful responses.

After obtaining written consent from the students, Dundee Ready Educational Environment Measure $(\mathrm{DREEM})^{2}$ was administered to the students. Each item in the tool was to be rated using a 5 point likert scale ranging from strongly agree (score-4) to strongly disagree (score-0). All questionnaires were distributed and returned the same day which allowed us to achieve a $100 \%$ response rate.

Statistical analysis: It was performed using Microsoft Excel and Scores of individual domains \& global scores were computed. Data was analyzed by computing mean and standard deviation.

Observations \& results:

The overall mean global DREEM score of our study population was $121.47 \pm 13.71$ (Out of 200).

Scores of each domain were as shown in table no.1.

Table 1: Mean \& SD of participants' DREEM scores in each domain

\begin{tabular}{|l|l|l|}
\hline Domain & Maximum score & Mean \pm SD \\
\hline Students' perception of learning & 48 & $29.27 \pm 6.24(61 \%)$ \\
\hline Students' perception of teachers & 44 & $27.42 \pm 4.47(62 \%)$ \\
\hline Students' academic self-perception & 32 & $20.78 \pm 4.46(65 \%)$ \\
\hline Students' perception of Atmosphere & 48 & $27.83 \pm 6.15(58 \%)$ \\
\hline Students' social self- perception & 28 & $16.17 \pm 3.62(57 \%)$ \\
\hline Total & 200 & $121.47 \pm 13.71(60.5 \%)$ \\
\hline
\end{tabular}


There was no statistically significant difference between the mean scores for the contributory DREEM domains, which were as follows: perception of learning, $29.27 / 48(60 \%)$;

perception of teachers, $27.42 / 44(62 \%)$;

academic self-perception, 20.78/32 (64\%);

perception of atmosphere, $27.83 / 48(58 \%)$,

and social self-perception, 16.17/28 (57\%).

In our study, there were 30 items which were scored between 2.50 and 3.00. These items are aspects of the educational environment that could be enhanced.

Table 2 : Items which were scored between 2.00 and 2.50

\begin{tabular}{|l|l|}
\hline $\begin{array}{l}\text { Item } \\
\text { Number }\end{array}$ & \\
\hline 9 & The teachers are authoritarian \\
\hline 48 & The teaching is too teacher centred. \\
\hline 17 & Cheating is a problem on this course \\
\hline 27 & I am not able to memorize all I need. \\
\hline 28 & $\begin{array}{l}\text { I feel lonely } \\
\text { The teaching over emphasizes factual learning }\end{array}$ \\
\hline 25 & $\begin{array}{l}\text { There is no good support system for students } \\
\text { who get stressed. }\end{array}$ \\
\hline
\end{tabular}

\section{Discussion}

Over the last four decades there has been growing interest in students' perceptions of their educational environment and the impact this may have on subsequent learning ${ }^{8,9}$. Educational research has demonstrated that the learning environment may influence student behaviour, academic achievement, course satisfaction and aspirations as well as sense of well-being ${ }^{10,11,12}$. Therefore, evaluation of the educational environment is an important consideration for any programmatic or curricular review ${ }^{13}$.

In our study, we have found the global score to be $121.47 \pm 13.71$ (out of 200). According to interpretation of the tool; this is labeled as more positive than negative. It indicates a satisfactory educational environment.
Using the same tool, other researchers have also evaluated educational environment at their institutes $\&$ have got comparable results ${ }^{14,15}$. Study of final year medical students in Trinidad reported global mean DREEM score of 109.9/200 ${ }^{1}$. A larger scale study, involving students from both final and earlier undergraduate training years, showed a DREEM score of 118/200 in a Nigerian medical school, and 130/200 in a Nepalese medical school ${ }^{16}$. The DREEM global scores for medical schools in Srilanka and UK were reported as $108 / 200 \& 139 / 200$ respectively ${ }^{17,18}$. I MBBS Students' perceptions of learning environment in an Indian medical school was found to be $119 / 200^{19}$.

Based on the responses of students, one can conclude that teaching in our institute is too teacher centered \& laying more stress on factual knowledge, students perceive teachers being authoritarian, students feel lonely, bored \& stressed out due to academic burden, there is issue of cheating during examinations $\&$ support system for students $\mathrm{t}$ is non-available. (These items are scored between $2 \& 2.5$; indicating that these shortcomings are not of severe nature). Steps are being taken to address these shortcomings e.g. we have started with a ward-teacher system in which seven to nine students are assigned to senior teachers \& regular meetings are scheduled to deal with students' problems. We are also stressing clinical \& practical relevance of various topics in the syllabus. Periodic assessment of DREEM score is also planned so as to know whether the remedial strategies are being helpful to improve educational environment at our institute.

\section{Conclusion}

Our global DREEM score is reassuring but, at the same time, our institute should strive for a score between 150 to 200 which indicates excellent educational environment. To achieve that we need to inculcate remedial strategies; some of which we have started with.

Ethical Clearance- was taken from the institution.

Source of Funding- Self

\section{Conflict of Interest: NIL}

\section{References}

1. Bassaw B, Roff S, McAleer S, Roopnarinesing S, Lisle JD, Teelucksing S, Gopaul S: Students' perspectives on the educational environment at Faculty of Medical Sciences, Trinidad.Med Teach 
$2003,25: 522-526$.

2. Sue Roff, Sean McAleer, Ronald M Harden, Mona Al-Qahtani, Ashraf Uddin Ahmed, Horacio Deza, Guido Groenen \& Praorn Primparyon (1997) Development and validation of the Dundee Ready Education Environment Measure (DREEM), Medical Teacher, 19:4, 295299.

3. De Oliveira Filho GR, Vieira JE, Schonhorst L. Psychometric properties of the Dundee Ready Educational Environment Measure (DREEM) applied to medical residents. Med Teach. 2005;27:343-347.

4. Jakobsson U, Danielsen N, Edgren G. Psychometric evaluation of the Dundee Ready Educational Environment Measure: Swedish version. Med Teach. 2011;33:267-274.

5. Till H. Identifying the perceived weaknesses of a new curriculum by means of the Dundee Ready Education Environment Measure (DREEM) Inventory. Med Teach. 2004;26:39-45.

6. Genn J: AMEE Medical Education Guide No. 23 (Part 1): curriculum, environment, climate, quality and change in medical education: a unifying perspective. Med Teach 2001, 23(4):337-344.

7. Hammond S, O'Rourke M, Kelly M, Bennett D, O'Flynn S: A psychometric appraisal of the DREEM. BMC Med Educ 2012, 12(1):2.

8. 19Miles S, Swift L, Leinster SJ: The Dundee Ready Education Environment Measure (DREEM): a review of its adoption and use. Med Teach 2012, 34(9):e620-e634.

9. 29 Genn J, Harden R: What is medical education here really like? Suggestions for action research studies of comates of medical education environments. Med Teach 1986, 8(2):111-124.

10. Audin K, Davy J, Barkham M: University Quality of Life and Learning (UNIQoLL): An approach to student well-being, satisfaction and institutional change. J Furth Higher Ed 2003, 27(4):365-382.
11. Plucker JA: The relationship between school climate conditions and aspirations conditions and student aspirations. J Educ Res 1998, 91(4):240260.

12. Genn J: AMEE Medical Education Guide No. 23 (Part 2) Curriculum, environment, climate quality and change in medical education - a unifying perspective. Med Teach 2001, 23(5):445-454.

13. Till H: Climate studies: can students' perceptions of the ideal educational environment be of use for institutional planning and resource utilization? Med Teach 2005, 27:332-337.

14. Pimparyon P, Roff S, McAleer S, Poonchai B, Pemba S: Educational environment, student approaches to learning and academic achievement in a Thai nursing school. Med Teach 2000, 22(4):359-365.

15. Vieira, J. E., Machado, J. L. M., \& Ribeiro, S. M. A. (2015). Assessment of the Environment with DREEM at a Medical School Using Active Methodologies and an Integrated Curriculum. Creative Education, 6, 1920-1935.

16. Roff S, McAleer S, Ifere OS, Bhattacharya S: A global diagnostic tool for measuring educational environment: comparing Nigeria and Nepal. Med Teach 2001, 23:378-382.

17. Jiffry MTM, McAleer, Fernandoo S, Marasinghe RB: Using theDREEM questionnaire to gather baseline information on anevolving medical school in Sri Lanka. Med Teach 2005, 27:348-352.

18. Varma R, Tiyagi E, Gupta JK: Determining the quality of educational climate across multiple undergraduate teaching sites using the DREEM inventory. BMC Med Educ 2005, 5(1):8.].

19. Abraham R, Ramnarayan K, Vinod P, Torke S. Students' perceptions of learning environment in an Indian medical school. BMC Med Educ. 2008;8:20. 